\title{
ІГОР ВОЙТОВИЧ
}

ORCID ID 0000-0003-2813-5225 ihor.voitovych@rshu.edu.ua доктор педагогічних наук, професор

Рівненський державний гуманітарний університет вул. Пластова, 31, м. Рівне

\section{РЕЦЕНЗІЯ НА НАУКОВУ МОНОГРАФІЮ Ю. П. БЕНДЕС, В. П. СЕРГІСНКА, В. Д. СИРОТЮКА «ТЕОРЕТИКО-МЕТОДИЧНІ ЗАСАДИ НАВЧАННЯ ФІЗИКИ МАЙБУТНІХ ФАХІВЦІВ ІТ-ГАЛУЗІ З ВИКОРИСТАННЯМ ІННОВАЦЙНИХ ТЕХНОЛОГІЙ»}

Автори монографії аргументовано доводять, що у зв'язку зі стрімким збільшенням кількості інформації, необхідність швидкої комунікації та обміну даними вимагають упровадження інформаційно-комунікаційних технологій (IКT) майже в усі сфери людської діяльності, зокрема й у підготовці фахівців IT. Особливого значення, на їх думку, мають педагогічні технології навчання фізики у технічних вищих навчальних закладах. Роль дисципліни «Фізика» у підготовці фахівців телекомунікаційної галузі можна визначити передусім, тим, що фізика - це фундамент науково-технічного прогресу, наукова основа сучасної техніки зв'язку. Фізика $є$ базовою дисципліною для вивчення таких дисциплін, як «Антени i поширення радіохвиль», «Електричні та квантові прилади НВЧ», «Електрозабезпечення», «Електротехнічні пристрої», «Основи схемотехніки», «Основи телебачення», «Теорія електричних кіл», «Технічна електроніка», «Фізика оптичного зв’язку», «Хімія та електрорадіоматеріали» та інших. При вивченні фізики треба забезпечувати можливості для ефективного здійснення професійної спрямованості навчання внаслідок поглиблення освітнього матеріалу тих розділів фізики, на яких грунтується техніка зв’язку, а саме: «Електрика та магнетизм», «Коливання і хвилі», «Хвильова оптика», «Фізика твердого тіла».

У своій роботі автори спираються на праці таких науковців, як П. Атаманчук, О. Бугайов, С. Гончаренко, М. Жалдак, І. Іваницький, А. Касперський, Є. Коршак, А. Павленко, О. Сергеєв, М. Шут, що засвідчило глибокий аналіз праць 3 проблеми навчання фізики, використовуючи інформаційно-комунікаційні технології в закладах освіти.

Автори обгрунтовують педагогічні умови реалізації освітнього потенціалу комп'ютерних технологій навчання майбутніх фахівців у галузі телекомунікацій, що їх забезпечують системним використанням візуалізації навчального матеріалу, безпосереднім зворотним зв'язком між користувачем та засобами комп'ютерних технологій, автоматизацією процесів інформаційно-методичного забезпечення, організацією управління навчальною діяльністю, контролю за результатами засвоєння знань. Створення особистісно орієнтованої комп'ютерної системи навчання фізики органічно узгоджено 3 провідними ідеями Болонського процесу відносно трансформації навчальної діяльності у процес переважно самостійного опрацювання освітнього матеріалу та поєднання навчання з науковими дослідженнями.

У першому розділі «Теоретичні аспекти застосування інноваційних технологій у навчанні фізики майбутніх фахівців IT галузі» проведено огляд науково-методичної та психологопедагогічної літератури i теоретичний аналіз специфіки підготовки майбутніх фахівців телекомунікацій, визначено місце та роль фізики в системі підготовки інженерів телекомунікаційного профілю, проаналізовано технологічний підхід в освіті, розглянуто сучасні уявлення про застосування інноваційних технологій під час навчання фізики, особливу увагу приділено інформаційним технологіям у системі підготовки інженерів телекомунікаційного профілю. Встановлено, що галузь телекомунікацій наразі перебуває на етапі революційних перетворень, які викликані глобалізацією виробничих і економічних процесів у світовому суспільстві, цьому відповідає зародження і розвиток нових технологій: поєднання комп'ютерних і телекомунікаційних систем; упровадження волоконно-оптичної техніки; розвиток цифрових методів і пристроїв передачі, зберігання і опрацювання даних. Неперервна освіта важлива категорія для фахівців телекомунікацій з огляду на швидкий розвиток техніки для передачі голосу, відео, систем передавання інформаційних ресурсів, Інтернетпослуг зв'язку та інтеграції засобів зв'язку з комп'ютерними мережами. 
Осмислення сутності, специфіки інженерної діяльності та функцій фахівців телекомунікацій спонукало авторів монографії до пошуку причиново-наслідкових зв'язків між професійною діяльністю, функціями, компетентностями майбутнього фахівця та системою навчання дисциплін циклу природничо-наукової підготовки взагалі i фізики зокрема. Основними компонентами компетентності фахівця телекомунікаційної галузі $є$ інструментальні компетентності та набір професійних компетентностей: виробничо-технологічні, організаційноуправлінські, науково-дослідницькі, проектні. У монографії представлено структуру моделі фахівця телекомунікаційної галузі в таких аспектах: психофізичному; когнітивному (наявність спеціальних знань 3 теорії та практики управління, інтелектуальна активність, володіння операціями розумової діяльності, творче мислення, критичність, гнучкість, оригінальність, дивергентність, асоціативність); рефлексивному (вміння здійснити самоаналіз та самооцінювання, коригування поведінки); мотиваційному (рівень мотивації досягнення, ціннісні установи, необхідність у самореалізації, лідерстві, творчості, самоактуалізації). 3'ясовано, що параметрами професійної компетентності фахівця телекомунікаційної галузі є: мотиваційний, когнітивний, операційний, особистісний, рефлексивний. Вказано, що ефективність функціонування технологій навчання фізики майбутніх фахівців телекомунікацій треба визначати психолого-педагогічними теоріями, які $є$ їх основою. Великі перспективи мають інноваційні технології, які створені у межах психологічної теорії діяльності: асоціативно-рефлекторної концепції навчання, теорії функціональних систем, теорії змістового узагальнення, теорії поетапного формування розумових дій, теорії випереджувального навчання. Тому курс фізики за змістом має відображати систему професійної спрямованості фізичних знань, сприяти формуванню системи фахових умінь.

На основі проведеного аналізу досліджень навчально-методичного забезпечення курсу фізики для студентів телекомунікаційних навчальних закладів автори встановили, що гостро стоїть проблема вдосконалення навчально-методичного забезпечення. Теперішнє навчальнометодичне забезпечення курсу фізики у вищих навчальних закладах телекомунікаційного напряму підготовки не забезпечує належного формування фізичних знань i подальшого ефективного їх використання у майбутній професійній діяльності. Процес навчання фізики має бути побудований так, щоб кожен його компонент відображав принцип професійної спрямованості навчання.

Другий розділ «Методична система навчання фізики майбутніх фахівців IT галузі 3 використанням інноваційних технологій» присвячено розробленню і впровадженню нових форм організації та технології ведення освітнього процесу. Створення комп'ютерної особистісно орієнтованої системи навчання органічно узгоджено із провідними ідеями Болонського процесу щодо трансформації навчальної діяльності в процес переважно самостійного опрацювання матеріалу та поєднання навчання 3 науковим дослідженням. Розроблена методична система містить у собі широке використання міжпредметних зв'язків, опорних конспектів, комп'ютерного моделювання, комп'ютерного вимірювального комплексу, контрприкладів, мультимедіаматеріалів, електронних підручників, комп'ютерного контролю та самоконтролю знань, освітнього сайту, сервісу мікроблогів, сайту колективної роботи 3 електронними документами, сторінок в соціальних мережах. Усі ці методичні прийоми окремо чи в певних комбінаціях використовують досить часто, але при поєднанні в єдиний комплекс творчого викладання фізики вони стали новою методичною системою.

Другий розділ також присвячений створенню та використанню універсального навчально-методичного комп'ютерного комплексу «еФізика», в якому головну роль приділено розробленню і впровадженню нових форм організації та технології ведення освітнього процесу. У ньому детально описано робочу модульну планувальну документацію, рейтингову систему оцінювання, алгоритми їх проведення, приклади контрольних модульних завдань. Крім сукупності модульних планів, в «еФізиці» міститься інтерактивний посібник та курс лекцій, збірник задач, завдання для тестового контролю знань.

У третьому розділі «Моделювання у процесі навчання фізики студентів IT напряму підготовки» розглянуто підходи до використання моделювання фізичних процесів у процесі підготовки майбутніх телекомунікаційників. Економічні та соціальні, технологічні та інформаційні реалії сучасного суспільства вимагають високошвидкісного інформаційного обміну даними, тому якісна підготовка фахівців у галузі телекомунікацій $є$ одним із пріоритетних завдань. До того ж, основною метою професійної освіти стає не лише підготовка кваліфікованого працівника відповідного профілю, а й становлення особистості, для якої 
важливо володіти професійною компетентністю, методами ефективної роботи за спеціальністю, мати творче мислення, орієнтуватися у динаміці своєї професії та у суміжних галузях діяльності. Упродовж останніх років у комп'ютерному моделюванні як форма навчальнодослідницької роботи, що активізує пізнавальну діяльність, максимально враховано індивідуальні особливості та диференціацію навчання, воно посіло чільне місце серед методів навчання. У цьому розділі розглянуто розроблення програмного моделюючого комплексу для вивчення властивостей поширення електромагнітних хвиль різних діапазонів. Під час опису тих чи інших властивостей наведено варіанти їхнього застосування в техніці зв'язку.

Окрім цього, проаналізовано мови програмування та здійснено вибір інтегрованого середовища Delphi 7 для розроблення моделюючих програмних додатків. На основі розробленого алгоритму написано комп'ютерні програми, що дають змогу розрахувати множник ослаблення під час поширення електромагнітних хвиль, за допомогою якого може бути визначена напруженість поля або інтенсивність у визначеній точці. Унаслідок цього створено три програми: одна призначена для визначення множника ослаблення траси поширення радіохвиль і дві - для розгляду властивостей хвиль оптичного діапазону. Крім вище зазначених програм, у розділі наведено такі програми для моделювання: «Геометрична оптика. Закон Брюстера», «Поляризація світла. Закон Малюса», «Дифракція світла на решітці та щілині», «Додавання однаково напрямлених коливань. Биття», «Додавання взаємно перпендикулярних коливань. Фігури Ліссажу», «Вивчення електронного осцилографа», «Дослідження термоелектронної емісії», «Реальні та ідеальні гази», «Балістика», які об’єднані в навчально-методичний комплекс «еФізика». Комплекс створено як комп’ютерне середовище, яке об'єднує зміст навчальної дисципліни і бази даних інформаційних ресурсів. Його використовують під час проведення занять 3 «Фізики», «Хімії та електрорадіоматеріалів» i «Фізики оптичного зв'язку», а також може бути застосований на практичних заняттях з низки технічних дисциплін.

Застосування розроблених моделюючих програм дає змогу отримувати наочні динамічні ілюстрації фізичних процесів та явищ, відтворювати їх деталі, які часто непомітні при спостереженні реальних явищ та експериментів, забезпечує можливість здобуття числової та графічної інформації на будь-якій стадії розрахунків і професійну орієнтованість курсу фізики, що забезпечує можливість підняти на якісно новий рівень самостійну роботу студентів. Розроблений програмний продукт дає можливість розв'язувати задачі 3 подальшою комп'ютерною перевіркою, яка посилює пізнавальний інтерес студентів, робить їх роботу творчою, до того ж, здебільшого наближує ії за характером до наукового дослідження.

У монографії також з'ясовано, що сучасні досягнення цифрової техніки та комп'ютерних технологій значно випереджають матеріальну базу й технологію освітнього експерименту в школах і ЗВО, тому четвертий розділ «Використання цифрових пристроїв та комп'ютерної техніки в навчальному експерименті з фізики» присвячений розробленню комплексу апаратних i програмних засобів, які забезпечують проведення автоматизованих лабораторних і навчальнодослідницьких робіт на фізичних і технічних об'єктах. У розділі проаналізовано різні типи аналого-цифрових перетворювачів та їх класифікацію, запропоновано методичний підхід до пояснення принципу роботи АЦП послідовного наближення, який полягає у поєднанні часової діаграми 3 логічною схемою роботи та комп’ютерною моделлю. Тому для підвищення ефективності вивчення процесів АЦП перетворень розроблено імітаційну модель для їх віртуальних досліджень у програмі «Multisim». Окреслено шляхи актуалізації та інтеграції знань з вищої математики, фізики, схемотехніки, матеріалознавства, які необхідні при створенні апаратних засобів комп'ютерної вимірювальної лабораторії. Зроблено порівняльний аналіз типів інтерфейсів підключення зовнішніх цифрових вимірювальних пристроїв до комп'ютера, головними параметрами якого було оптимальне співвідношення таких критеріїв: вартості реалізації пристрою, технічних характеристик та дидактичних можливостей. Проаналізовано сучасні методики використання інформаційно-телекомунікаційних технологій у навчальному експерименті 3 фізики, розглянуто відомі розробки комп'ютерних вимірювальних лабораторій з фізики, виявлено їх позитивні та негативні сторони. Усе це представлено в розділі програми для проведення експериментів і об'єднано в навчальнометодичний комплекс «еФізика». Вимірювальна частина цього комплексу дає змогу автоматизувати процес дослідження та керування експериментом; прискорити процеси проведення вимірювань, накопичення та опрацювання даних; скоротити час на підготовку та 
проведення дослідів, дають можливість зберігати результати в зручному вигляді для подальшого опрацювання; підвищити їх точність та достовірність.

У п’ятому розділі «Методика використання комп'ютерних технологій у процесі проведення лабораторних робіт 3 фізики» розроблено триєдиний підхід до виконання лабораторних робіт з фізики. Розділ присвячено розробленню, виготовленню і впровадженню засобів сучасної електроніки й комп'ютерної техніки в навчальний фізичний експеримент. Науково-методично обгрунтовано доцільність використання цих засобів на основі сучасних уявлень та тенденцій розвитку фізичного експерименту, розглянуто методичні особливості використання сучасних електронних приладів та комп'ютерної техніки в навчальному експерименті з фізики. Розроблено і експериментально апробовано методику використання електронного обладнання та комп'ютерної техніки в навчальному процесі під час вивчення питань актуальних для майбутніх фахівців телекомунікаційної галузі, яка дає змогу реалізувати принцип професійної спрямованості та підвищити ефективність вивчення фізики. Теперішнє навчально-методичне забезпечення лабораторних робіт 3 курсу фізики у вищих телекомунікаційних навчальних закладах не забезпечує належного формування фізичних знань i подальшого ефективного їх використання у майбутній професійній діяльності. На основі використання засобів сучасної електроніки та комп'ютерної техніки виготовлено і апробовано нове обладнання, що дало можливість удосконалити матеріальну базу освітнього фізичного експерименту та розширити його дидактичні можливості. Ці установки доступні для самостійного виготовлення і реалізації студентами напряму підготовки «Телекомунікації».

Запропоноване авторами обладнання та методика його використання дають змогу поновому підійти до постановки, проведення, опрацювання, аналізу та збереження даних експериментальних досліджень за допомогою ПК. Створено і впроваджено у практику навчально-методичний комплекс, який містить навчально-методичний контент. Застосування описаних технологій має комплексний, системний характер, охоплює весь процес навчання та внесене в блоки фундаментальної й професійної підготовки. Використання розробленого обладнання, програмного забезпечення та методики його використання сприяють інтенсифікації освітнього процесу, підвищенню наукового рівня вивчення актуальних питань фізики, розширюють інформативність навчання, дають можливість навчити студентів прийомів експериментально-дослідницької діяльності і реалізовувати ідеї розвивального та проблемного навчання, сприяють професійній спрямованості дисципліни та формуванню наукового світогляду, активізації пізнавальної діяльності та розвитку інтелектуальних здібностей.

Отже, автори монографії змогли виконати поставлені завдання і дійти таких висновків:

1. Дисципліна «Фізика» $\epsilon$ основною дисципліною природничо-наукового циклу для студентів напряму підготовки «Телекомунікації», а тому необхідність підвищення якості фахової підготовки майбутніх інженерів телекомунікаційного профілю ставить посилені вимоги до змісту і форми викладення освітнього матеріалу з фізики. Проте професійно орієнтована підготовка майбутніх фахівців телекомунікацій ускладнюється відсутністю обгрунтованого концептуального підходу до іï організації, навчально-методичного забезпечення та упровадження. У зв'язку з цим істотне поліпшення підготовки майбутнього фахівця у галузі телекомунікацій, посилення її прогностичної спрямованості можливе лише за умови розроблення теоретичних і методичних основ використання інноваційних технологій навчання фізики: модульної, інформаційної та проектної.

2. Розроблено методичну систему навчання фізики студентів напряму підготовки «Телекомунцікації», яка містить такі основні складові, як зміст курсу фізики, методи, засоби і технології навчання, форми його організації, навчальні й інформаційні ресурси. Особистісно орієнтована система навчання органічно узгоджується із провідними ідеями Болонського процесу щодо трансформації навчальної діяльності в процес самостійного опрацювання матеріалу та поєднання навчання з науковим дослідженням.

3. Створено універсальний навчально-методичний комп'ютерний комплекс «еФізика», спрямований на впровадження нових форм організації та технологій реалізації освітнього процесу. Особливу увагу приділено модульній технології, яка забезпечує варіативність та індивідуалізацію навчання і дає можливість ефективно реалізувати принципи систематичності, науковості і наступності фізичної освіти, а також підвищити рівень професійної підготовки майбутніх фахівців телекомунікацій.

4. Розроблено комп'ютерні моделі з використанням комп'ютерного навчально-методичного комплексу «еФізика» у процесі вивчення питань курсу фізики, що $є$ актуальними для 
професійної діяльності майбутніх фахівців телекомунікацій. Комп'ютерні моделі на основі експериментальних даних, забезпечують динамічну візуалізацію даних, здобутих у реальному експерименті; порівняння поведінки реального об'єкта та комп'ютерної моделі; отримання за допомогою комп'ютерної моделі нових залежностей із використанням експериментальних даних. 3'ясовано, що розроблені комп'ютерні моделі посилюють пізнавальний інтерес студентів, роблять їх роботу творчою і наближують ії до наукового дослідження.

5. Обгрунтовано, що оптимальні умови реалізації дидактичного потенціалу комп’ютерних технологій навчання майбутніх фахівців у галузі телекомунікацій полягають у системному використанні принципу візуалізації навчального матеріалу, безпосередньому зворотному зв'язку між користувачем та засобами комп'ютерних технологій, автоматизації процесів інформаційно-методичного забезпечення, організації управління навчальною діяльністю, контролі за результатами засвоєння.

6. Створено освітній WEB - сайт для організації взаємодії між суб'єктами освітнього процесу та для зниження часових і фінансових затрат у сучасних умовах. Його використання сприяє інтеграції в загальноукраїнський та світовий освітній простір та забезпечує такі можливості: оперативне поширення навчально-методичної інформації, формування, зберігання і супровід інформаційних баз даних, створення методичного консультаційного центру, надання послуг для забезпечення дистанційної освіти, забезпечення індивідуалізації освіти.

7. Використання навчально-методичного комплексу «еФізика» у навчанні фундаментальних та технічних дисциплін забезпечує: поєднання освітнього і методичного контенту, моделюючих програм та універсальних комп'ютерних вимірювальних пристроїв найдоцільнішим та економічним способом; незалежність від типу комп'ютерної платформи, динамічність та відкритість системи, яка ідеально підходить для збирання, зберігання, аналізу даних та їх презентації; відповідність до сучасних освітніх і технічних стандартів, а також можливість широкого використання для вимірювання й автоматизації.

Монографія безперечно $є$ значним внеском у розвиток теорії і методики навчання фізики і рекомендована до використання дослідниками та науковцями в цій та суміжних галузях. 